\title{
Pengaruh Penerapan Akuntansi Pertanggungjawaban Terhadap Prestasi Kerja Karyawan Pt. PLN (Persero) Area Jember
}

\author{
Irma Fatimah $^{1 *}$, Norita Citra Yuliarti ${ }^{2}$, Astrid Maharani ${ }^{3}$ \\ 1,2,3 Jurusan Akuntansi, Fakultas Ekonomi, Universitas Muhammadiyah Jember
}

\section{A R T I C L E I N F O}

Article history:

Received 19 May 2018

Received in revised form

10 June 2018

Accepted 12 July 2018

Available online 25 August 2018

Kata Kunci:

Akuntansi

pertanggungjawaban,

prestasi kerja

Keywords:

Responsibility Accounting,

Job Performance.

\begin{abstract}
A B S T R A K
Tujuan penelitian ini menguji pengaruh penerapan akuntansi pertanggungjawaban terhadap prestasi kerja. Sampel yang digunakan penelitian ini yaitu 60 responden. Teknik penentuan sampel menggunakan metode purposive sampling. Pengumpulan data menggunakan teknik wawancara dan kuesioner. Hipotesis penelitian diuji dengan menggunakan metode regresi sederhana. Berdasarkan pengujian hipotesis menunjukkan bahwa penerapan akuntansi pertanggungjawaban berpengaruh signifikan terhadap prestasi kerja. Dimana hasil analisi pada akuntansi pertanggungjawaban berpengaruh signifikan terhadap prestasi kerja ditunjukkan t hitung $(19,783)>t$ tabel $(1,67203)$.
\end{abstract}

\section{A B S T R A C T}

This study aimed to test the influence of the implementation of responsibility accounting of the job performance. This research is used 60 samples of respondents. Data obtained by the method of purposive sampling. The data was collected using a interviews and quistionnaire. Research hypotesis were tasted using simple regression method. Based on hypothesis testing the result showed of this research, it can be concluded that the implementation of responsibility accounting effect significantly to the job performance. Where the result of analysis on the responsibility accounting have a significant effect on job performance show t count $(19,783)>t$ table $(1,67203)$.

\footnotetext{
* Corresponding author.

E-mail addresses: ermafa626@ gmail.com (Irma Fatimah),
} 


\section{Pendahuluan}

Setiap perusahaan yang didirikan pada dasarnya untuk mencapai suatu tujuan, yakni untuk mendapatkan laba yang maksimum, melayani dan meningkatkan kepuasan konsumen serta menjaga dan melaksanakan aktivitas didalam perusahaan.Untuk mencapai tujuan, sebuah perusahaan memerlukan suatu pedoman yang berupa tugas, wewenang dan tanggung jawab bagi masing-masing bagian organisasi secara jelas dan tepat (Handayani, 2010).

Akuntansi pertanggungjawaban yaitu proses pengukuran hasil pusat prtanggungjawaban berdasarkan kebutuhan manajer yang mmberika cerminan rencana, usahan dan hasil untuk menjalankan sistematika stratgi perusahaan (Rudianto, 2006). Akuntansi pertanggungjawaban adalah prosedur akuntansi yang dierlukan sebagai proses pengukuran tingkat kinerja masing-masing pusatp prtanggungjawaban berdasarkan kebuutuhan bagian manajer dalam menjalankan pusat-pusat pertanggungjawaban yang merupakan bagian dari prosdur pengendalian (Samryn, 2012). Akuntansi pertanggungjawaban adalah salah satu alat terbaik dalam manajemen biaya yang digunakan dalam perusahaan atau organisasi yang memiliki ruang lingkup yang besar dalam melakukan desentralisasi dan divisional untuk mengelola perusahaan (Suari Ardiani, 2013). Akuntansi pertanggungjawaban merupakan aslah satu konsep dari akuntansi manajemen dan sistem akuntansi yang dikaitkan dan disesuaikan dengan pusat-pusat pertanggungjawaban yang ada dalam organisasi (Sari, 2013). Akuntansi pertanggungjawaban sosial (Social Responsibility Accounting) didefinisikan sebagai proses seleksi variabel-variabel kinerja sosial tingkat perusahaan, ukuran dan prosedur pengukuran, yang secara sistematis mengembangkan informasi yang bermanfaat untuk mengevaluasi kinerja sosial perusahaan dan mengkomunikasikan informasi tersebut kepada kelompok sosial yang tertarik, baik di dalam maupun di luar perusahaan (Marina,2009).

Secara objektif pelaksanaan pertanggungjawaban wajib dijalankan, dikarenakan menjadi cerminan hasil perusahaan. Fungsi pelaporan pertanggungjawaban yaitu alat penilaian prestasi kerja terhadap karyawan ataupun manajer, prestasi kerja diterapkan dengan proses pembandingan pelaksanaan dengan anggaran dana. Suatu penilaian prestasi kerja perlu adanya tolak ukur agar mendorong dan memotivasi pelaksana dalam mencapai tujuan perusahaan (Muharam, 2011). Pusat pertanggungjawaban merupakan unit divisi yang berada di bawah wewenang dan tanggugjawab pimpinan manajer dengan segala kgiatan yang dilakukan dengan memanfaatkan kegunaan sistem kontrol informasi terhadap pengambilan keputusan jangka pndek ataupun jangka panjang (Anthony, 2009).

Menerapkan sistem akuntansi pertanggungjawaban tidaklah mudah, dikarenakan ada bebrapa syarat yang harus dipenuhi, diantaranya organisasi perusahaan harus trdiri dari pusat-pusat prtanggungjawaban sehingga pembuatan keputusan tidak sepihak, melainkan melibatkan karyawan secara keseluruhan dibawah kebijakan manajer (Daniel, 2011). Memanfaatkan efisiensi dan keefktifan perusahaan diharuskan memiliki struktur organisasi dan job dscription yang terperinci untuk menerapkan akuntansi pertanggungjawaban (Mulyadi, 2001).

Pimpinan diwajibkan melakukan pedelegasian wewenang serta tanggungjawab penting ketingkat pimpinan bawah atau disebut pra pelaksana dalam pengambilan keputusan, sehingga masalah dapata diatasi dengan lebih baik. Adanya suatu pendelegasian peran akan menimbulkan berbagai tingkat tanggung jawab dana wewenang dalam suatu perusahaan. (Lestari, 2011).

Permasalah yang muncul pada perusahaan yakni kinerja karyawan yang terlihat menurun dapat dilihat tabel 1.1 mengenai tingkat absensi ketidakhadiran karyawan dibulan Januari-Februari yaitu 2 karyawan, dibulan Maret-Mei yaitu 3 karyawan, dibulan Juni-September yaitu 4 karyawan, dan dibulan Oktober-Desember yaitu 5 karyawan. Tingkat absensi ketidakhadiran karyawan semakin meningkat, dikarenakan beberapa permaslahan yakni kurangnya pengawasan yang dilakukan atasannya maupun dorongan atau motivasi dari sesama rekan kerja, karyawan yang bersantai ria dalam bekerja serta sesama karyawan keluar masuk kantor lebih awal. Permasalahan ini menyebakan pekerjaan tidak baik dan lebih banyak mengulur waktu untuk menyelesaikannya. Hal ini menyebabkan prestasi kerja juga mengalami penurunan. Prestasi kerja adalah pencapaian hasil kerja individu selama menjalankan amanah yang diberikan prusahaan brdasarkan keahliannya guna mencapai hasil secra kualitas dan kuantitas yang wajib di perhatikan pihak manajer dengan menggunakan feed back dan memungkinkan keluar hasrat motivasi dalam menjalankan tanggungjawab (Hasibuan, 2007). Proses penilaian prestasi kerja merupakan cara mengeksekusi pekerjaan karyawan berdasarkan perbandingan standar yang digunakan, kemudian mengkoordinasikan informasi seobjektif mungkin yang secara mutlak diperhatiak manajer dan pemberian manfaat terhadap manajemen perusahaan (Malthis, 2006).

Berdasarkan uraian fenomena dan penjelasan diatas, peneliti melakukan penelitian guna mengetahui apakah penerapan akuntansi pertanggungjawaban berpengaruh terhadap prestasi kerja karyawan PT. PLN (Persero) Area Jember? 


\section{Metode}

Data primer merupakan perolehan sumber data secara langsung melalui responden untuk menjawab penelitian. Metode survei merupakan teknik pemberian kuesioner, pemberian kuisioner kepada responden dijelaskan dan dikumpulkan kembali dari responden untuk memberikan penjelasan mengenai pertanyaan yang ada dalam kuesioner, dengan menggunakan metode survei peneliti mampu mengolah data (Indriantoro, 2008).

Uji validitas dilakukan untuk mengetahui valid tidaknya kuesioner. Suatu kuisioner disebut valid apabila kuesioner mampu dan dapat mengungkapkan suatu indikator yang diukur kuesioer (Ghozali, 2006). Uji reliabilitas merupakan alat untuk mengetahui suatu kuesioner dari indikator suatu variabel. Jika jawaban dan pertanyaan dari kuisioner konsisten maka kuisioner dengan indikator tersebut dikatakan reliabel. Ukuran uji reliabilitas menggunakan metode Cronbach Alpha dengan nilai lebih dari 0,06 (Ghozali, 2006). Analisis data penelitian ini menggunakan tingkat keyakinan 95\% atau $\alpha=5 \%$. Pengujian hipotesis ini menggunakan analisis regresi sederhana dengan asumsi persamaan sebagai berikut:

\section{$\mathbf{Y}=\mathbf{a}+\mathbf{b x}+\mathbf{e}$}

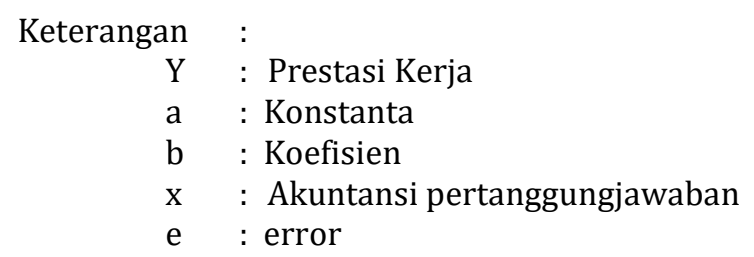

Tujuan uji normalitas yaitumelakukan pengukuran apakah didalam model regresi terdapat distribusi normal atau mendekati normal. Penelitian ini menggunakan uji normalitas dengan One Sample Kolmogrov-Smirnov Test, dengan kriteria pengujian sebagai berikut (Ghozali, 2006):

1. Jika $\mathrm{p}<0,05$ maka distribusi data dikatakan tidak normal

2. Jika $p>0,05$ maka distribusi data dikatakan normal

Uji heterokedastisitas bertujan untuk membuktikan apakah ada ketidaksamaan variancedalam regresi sederhana yang dilakukan penelitian dari waktu ke waktu sehingga disebut homoskedastisitas. Tujuan uji t yaitu membuktikan sejauh mana pengaruh variabel independen secara jelas dan dapat menjelaskan kegunaan variabel dependen. Untuk mengetahui pengaruh variabel independen berdasarkan indikator kuisioner dapat diuji dengan tingkat signifikansi 0,05 (Ghozali, 2005). Koefisien determinasi $\left(\mathrm{R}^{2}\right)$ digunakan sebagai proses ukuran penilaian model yang menjelaskan berbagai macam variasi. Nilai koefisien determinasi berkisar $0-1$. Koefisien yang menunjukkan besarnya presentase yangberpengaruh terhadap variabel dependen dengan tingkat signifikansi $5 \%$ atau 0,05 (Ghozali, 2006).

\section{Hasil dan pembahasan}

Statistik deskriptif merupakan informasi awal dalam menganalisis hasil jawaban responden. Penelitian deskriptif dari variabel independen maupun variabel dependen. Dibawah ini merupakan hasil statistik deskriptif:

Tabel 1. Statistik Deskriptif

\begin{tabular}{|lccccc|}
\multicolumn{1}{|c}{ Variabel } & $\mathbf{N}$ & Minimum & Maximum & Mean & $\begin{array}{c}\text { Std. } \\
\text { Deviasi }\end{array}$ \\
\hline $\begin{array}{l}\text { Akuntansi } \\
\text { Pertanggunngjawaban }\end{array}$ & 60 & 40 & 94 & 78,58 & 15,192 \\
\hline Prestasi Kerja & 60 & 21 & 51 & 41,87 & 41,87 \\
\hline
\end{tabular}


Variabel akuntansi pertanggungjawaban dari jawaban responden diperoleh rata-rata (mean) sebesar 78,58 artinya jawaban yang diberikan responden banyak menjawab setuju atas pernyataan dalam kuisioner dengan standar deviasi 15,192.

Uji Validitas

Hasil uji validitas masing-masing item pada variabel akuntansi pertanggungjawaban dan prestasi kerja sebagai berikut:

Tabel 2. Hasil Uji Validitas Variabel Akuntansi Pertanggungjawaban

\begin{tabular}{|c|c|c|c|c|}
\hline Item & $\mathbf{N}$ & Fhitung & rtabel & Keterangan \\
\hline X.1 & 60 & 0,703 & 0.214 & Valid \\
\hline$x .2$ & 60 & 0,758 & 0.214 & Valid \\
\hline$x .3$ & 60 & 0,752 & 0.214 & Valid \\
\hline$x .4$ & 60 & 0,620 & 0.214 & Valid \\
\hline$x .5$ & 60 & 0,712 & 0.214 & Valid \\
\hline$\times .6$ & 60 & 0,723 & 0.214 & Valid \\
\hline$x .7$ & 60 & 0,649 & 0.214 & Valid \\
\hline X.8 & 60 & 0,803 & 0.214 & Valid \\
\hline$x .9$ & 60 & 0,746 & 0.214 & Valid \\
\hline$x .10$ & 60 & 0,755 & 0.214 & Valid \\
\hline X.11 & 60 & 0,624 & 0.214 & Valid \\
\hline X.12 & 60 & 0,792 & 0.214 & Valid \\
\hline X.13 & 60 & 0,641 & 0.214 & Valid \\
\hline$x .14$ & 60 & 0,589 & 0.214 & Valid \\
\hline$x .15$ & 60 & 0,663 & 0.214 & Valid \\
\hline$x .16$ & 60 & 0,468 & 0.214 & Valid \\
\hline X.17 & 60 & 0,557 & 0.214 & Valid \\
\hline$x .18$ & 60 & 0,590 & 0.214 & Valid \\
\hline X.19 & 60 & 0,650 & 0.214 & Valid \\
\hline$x .20$ & 60 & 0,639 & 0.214 & Valid \\
\hline$x .21$ & 60 & 0,667 & 0.214 & Valid \\
\hline$x .22$ & 60 & 0,536 & 0.214 & Valid \\
\hline
\end{tabular}

Tabel 3. Hasil Uji Validitas Variabel Prestasi Kerja

Sumber: Data diolah

\begin{tabular}{|cllll|}
\hline Item & $\mathbf{N}$ & r ritung & rabel & Keterangan \\
\hline Y.1 & 60 & 0,771 & 0.214 & Valid \\
\hline$Y .2$ & 60 & 0,750 & 0.214 & Valid \\
\hline$Y .3$ & 60 & 0,768 & 0.214 & Valid \\
\hline$Y .4$ & 60 & 0,749 & 0.214 & Valid \\
\hline$Y .5$ & 60 & 0,778 & 0.214 & Valid \\
\hline$Y .6$ & 60 & 0,787 & 0.214 & Valid \\
\hline$Y .7$ & 60 & 0,746 & 0.214 & Valid \\
\hline$Y .8$ & 60 & 0,673 & 0.214 & Valid \\
\hline$Y .9$ & 60 & 0,778 & 0.214 & Valid \\
\hline$Y .10$ & 60 & 0,752 & 0.214 & Valid \\
\hline$Y .11$ & 60 & 0,852 & 0.214 & Valid \\
\hline$Y .12$ & 60 & 0,573 & 0.214 & Valid \\
\hline
\end{tabular}

Sumber: Data diolah

Kisaran nilai kolerasi ( $\mathrm{r}_{\text {hitung }}$ ) masing-masing item pertanyaan akuntansi pertanggungjawaban 0,468 sampai dengan 0,803 , sedangkan pada prestasi kerja kisaran nilai korelasi ( $r_{\text {hitung }}$ ) masing-masing item 0,573 sampai dengan 0,852, yang mengandug arti bahwa variabel akuntansi pertanggungjawaban dan prestasi kerja valid.

Tabel 4. Hasil Uji Reliabilitas

\begin{tabular}{|ccc|}
\hline Variabel & Alfa-Cronbach & Keterangan \\
\hline Akuntansi pertanggungjawaban (X) & 0,941 & Reliabel \\
\hline Prestasi Kerja (Y) & 0,928 & Reliabel \\
\hline
\end{tabular}


Tabel 4 diperoleh nilai Alfa-Cronbach akuntansi pertanggujawaban sebesar 0,941 dan variabel prestasi kerja sebesar 0,941. Nilai Alfa-Cronbach masing-masing variabel lebih besar dari 0,06 maka variabel penelitian dikatakan reliabel.

\section{Tabel 5 Uji Normalitas}

\begin{tabular}{|ccc|}
\hline Variabel & Sig. & Keterangan \\
\hline $\begin{array}{c}\text { Akuntansi Pertanggungjawaban } \\
(\mathrm{X})\end{array}$ & 0,101 & Normal \\
\hline Prestasi Kerja (Y) & 0,101 & Normal \\
\hline
\end{tabular}

Sumber: Data diolah

Berdasarkan uji normalitas variabel akuntansi pertanggungjawaban sebesar 0,101 dan variabel prestasi kerja sebesar $0,101<\alpha(0,05)$ sehingga hasil menunjukkan bahwa menyebar menurut distribusi normal.

\section{Uji Heteroskidastisitas}

Dari grafik scatterplot heteroskedastisitas menunjukkan penyebaran titik-titik tertentu dengan jelas baik diatas ataupun dibawah angka 0 sumbu Y. Hal ini menunjukkan tidak adanya penyimpangan asumsi klasik heteroskedastisitas.

\section{Regresi Linier Sederhana}

Berdasaran hasil perhitungan, akan diperoleh hasil analisis sebagaimana tabel berikut ini:

\section{Tabel 6 Rekapitulasi Hasil Analisis Regresi Sederhana}

\begin{tabular}{|c|c|c|}
\hline $\begin{array}{l}\text { Koefisien } \\
\text { Regresi }\end{array}$ & $\begin{array}{l}\text { Penyajian Hipotesis } \\
\text { T T tabel } \\
\text { hitung }\end{array}$ & Sign \\
\hline $\begin{array}{l}\text { Akuntansi } \\
\text { Pertanggungjawaban } \\
\text { (X) }\end{array}$ & $19.783 \quad 1.67203$ & $\mathbf{0 0 0}$ \\
\hline $\mathbf{R}=\mathbf{0 . 9 3 3}$ & Fratio & $=391.354$ \\
\hline$=0.871$ & Signifikansi & $=\mathbf{0 , 0 0 0}$ \\
\hline Adjos $\mathbf{R}^{2}$ & Constanta & $=\mathbf{5 . 8 1 8}$ \\
\hline
\end{tabular}

\section{Sumber: Data diolah}

Berdasarkan hasil analisis yang dilakukan, diperoleh persamaan regresi yaitu: $\mathrm{Y}=5.818+0.607 \mathrm{X}$. Koefisien 0.607 menunjukkan bahwavariabel akuntansi pertanggungjawaban meningkat, jadi prestasi kerja meningkat 0.607 sebaliknya apabila akuntansi pertanggugjawaban menurun maka prestasi kerja akan menurun sebesar 0.607.

Berdasarkan tabel 6, maka pengujian hipotesis secara parsial memiliki thitung 19.783 dengan tingkat signifikansi $t_{\text {hitung }} 0,000$. Hal ini menunjukkan bahwa $t_{\text {hitung }}>t_{\text {tabel }}(19,783>1,67203)$ dan nilai signifikansi $>0,05$.

\section{Koefisien Determinasi ( $\left.\mathbf{R}^{2}\right)$}

Tabel 7 Koefisien Determinasi

\begin{tabular}{ll|} 
R Square & $\begin{array}{l}\text { Adjusted } \\
\text { Square }\end{array}$ \\
\hline 0.871 & 0.869 \\
\hline
\end{tabular}

Sumber: Data diolah

Koefisien determinasi $\left(\mathrm{R}^{2}\right)$ digunakan sebagai proses ukuran penilaian model yang menjelaskan berbagai macam variasi. Nilai koefisien determinasi berkisar 0-1. Koefisien yang menunjukkan besarnya presentase yangberpengaruh terhadap variabel dependen dengan tingkat signifikansi $5 \%$ atau 0,05 (Ghozali, 2006). 


\section{Simpulan dan saran}

Hasil dan analisis yang telah dilakukan, maka kesimpulan yang dapat ditarik adalah,penerapan akuntansi pertanggungjawabanberpengaruhsignifikan terhadapprestasikerja berdasarkan PT. PLN (Persero) Area Jember yaitu kinerja karyawan yang terlihat menurun, mengenai tingkat absensi ketidakhadiran karyawan dibulan Januari-Februari yaitu 2 karyawan, dibulan Maret-Mei yaitu 3 karyawan, dibulan Juni-September yaitu 4 karyawan, dan dibulan Oktober-Desember yaitu 5 karyawan. Tingkat absensi ketidakhadiran karyawan semakinmeningkat, disebabkan oleh beberapa permasalahan yaitu yang dilakukan atasanmaupun dorongan dari sesama rekan kerja, sikap bersantai santai saat kelangsungan kerja, tidak memanfaatkan waktu dengan baik saat.

\section{Daftar Rujukan}

Damayanti, Theresia Woro. 2009. Audit Pertanggungjawaban Sosial Perusahaan: Pendekatan Literatur. Jurnal Akuntansi dan Keuangan, Vol.11, No.2

Ghozali, Imam. 2006. Analisis Multivariate Dengan Program SPSS. Cetakan Keempat. Semarang: Badan Penerbit Universitas Diponegoro.

Handayani, Rika. 2010. Akuntansi Pertanggungjawaban Sebagai Alat Bantu Manajemen Dalam Pengendalian Biaya (Studi Kasus Pada PT. Pelabuhan Indonesia I). Skripsi. Medan: Fakultas Ekonomi Universitas Sumatra Utara.

Hansen, Don R. Dan Maryanne M. Mowen. 2005. Management Accounting : Akuntansi Manajemen. Edisi Ketujuh. Buku 2. Jakarta: Salemba Empat.

Hasibuan, Malayu. 2007. Manajemen Sumber Daya Manusia. Edisi Revisi. Jakarta: Bumi Aksara.

Hidayat, Taufik. 2012. Analisis Pengaruh Penerapan Akuntansi Pertanggungjawaban Terhadap Kinerja Manajer Pusat Laba di Warung Paskal Bandung. Jurnal Akuntansi Maranatha, Vol.4, No.2.

Hutabarat, Goodman. 2009. Hubungan Penerapan Akuntansi Pertanggungjawaban dengan Efektivitas Pengendalian Biaya, Jurnal Ilmiah Satya Nugraha Indonesia, Vol.2 No.1.

Iswati, Sri. 2007. Internalisasi Akuntansi Pertanggungjawaban melalui Reward yang Syar'i, Jurnal Akuntansi, Manajemen Bisnis, dan Sektor Publik, Vol. 4 No.1. h:1-16.

Indriantoro, Nur dan Supomo, Bambang. 2008. Metodologi Penelitian Bisnis untuk Akuntansi dan Manajemen. Yogyakarta: BPFE-Yogyakarta.

Komar, Seful. 2004. Akuntansi Pertanggungjawaban Sosial (Social Responsibility Accounting) dan Korelasinya dengan Akuntansi Islam. Media Akuntansi. Edisi 42/Tahun XI, hal. 54-58

Lestari, Yovita, R.R. 2011. Pengaruh Penerapan Akuntansi Pertanggungjawaban Terhadap Kinerja Manajerial Pada Perusahaan Manufaktur, Skripsi. Palembang: Sekolah Tinggi Ilmu Ekonomi MUSI.

Marina, Anna. 2009. Akuntansi Pertanggungjawaban Sosial Dalam Praktek Di Perusahaan go Publik Di Indonesia. Jurnal Balance, Vol.3, No.1.

Muharam, Regi. 2011. Akuntansi Pertanggungjawaban Sebagai Alat Pengendalian Biaya dan Penilaian Prestasi Kerja. http://oboutz.wordpress.com/2011/11/18 [20 Februari 2013].

Prawironegoro, Darsono dan Purwati, Ari. 2008. Akuntansi Manajemen. Edisi Kedua. Mitra Wacana Media. Jakarta.

Rani,Falentina. 2018. Pengaruh Integritas, Kompetensi, Dan Profesionalisme Terhadap Produktivitas Kerja Karyawan Bagian Akuntansi Pada Pt. Bank Mandiri (Persero) Tbk Manado. Jurnal Riset Akuntansi Going Concern, Vol.13, No.3. 
Sari, Dian. 2013. Pengaruh Partisipasi Anggaran Dan Akuntansi Pertanggungjawaban Terhadap Kinerja Manajerial PT. Pos Indonesia. E-Jurnal Binar Akuntansi, Vol.2, No.2.

Supriyono, R. A. 2005. Sistem Pengendalian Manajemen. Edisi Revisi. Buku 2. Yogyakarta: BPFE-UGM.

Suari Ardiani, Ni Made dkk. 2013. Pengaruh Penerapan Akuntansi Pertanggungjawaban Terhadap Efektivitas Pengendalian Biaya. Jurnal Akuntansi, Vol.5, No.3.

Suaryana, Agung. 2011. Implementasi Akuntansi Sosial dan Lingkungan di Indonesia. Jurnal Ilmiah Akuntansi dan Bisnis, Vol.6, No.1.

Sriwidodo, Untung. 2010. Informasi Akuntansi Pertanggungjawaban sebagai Alat Penilaian Kinerja Manajer. Jurnal Akuntansi dan Sistem Teknologi Informasi Vol. 8 No.1. h:18-24.

Yuli, Sri Budi Cantika, 2005. Manajemen Sumber Daya Manusia. Malang: UMM Press. 